\title{
Modified Björk Analysis of Lateral Head Radiographs of Southern Chinese
}

\author{
John Y.C. Wu ${ }^{1}$, Urban Hägg ${ }^{1}$, Ricky W.K. Wong ${ }^{1, *}$ and McGrath Colman ${ }^{2}$ \\ ${ }^{I}$ Orthodontics and ${ }^{2}$ Dental Public Health, Faculty of Dentistry, The University of Hong Kong, Hong Kong SAR, China
}

\begin{abstract}
Aim: To establish cephalometric norms for the modified Björk's cephalometric analysis in southern Chinese children, and compare them to those of a matched Caucasian sample.

Materials and Methods: The material comprised lateral cephalometric radiographs of a random sample of 200 males and 205 females 12-year-old southern Chinese, and an additional sample of 43 males and 43 females 12-year-old British Caucasian children in Hong Kong. The radiographs were digitized twice with the Computer-Assisted Simulation System for Orthognathic Surgery (CASSOS) program.

Results: The results showed that there were statistically significant ethnic differences for 15 out of the 17 cephalometric variables $(\mathrm{P}<0.05-0.001)$. There were statistically significant ethnic differences for 11 variables in males $(\mathrm{P}<0.05-0.001)$ and 15 variables in females $(\mathrm{P}<0.05-0.001)$. The size of the statistically significant gender differences varied from -0.4 to $0.8(\mathrm{P}<0.05-0.001)$ in SD scores for Chinese and from 0.5 to $0.6(\mathrm{P}<0.01)$ for Caucasian. The size of the observed statistically significant ethnic differences varied from -1.7 to $1.3(\mathrm{P}<0.05-0.001)$ in SD scores for female and from -1.6 to 1.0 $(\mathrm{P}<0.05-0.001)$ for male.

Conclusion: Cephalometric norms for the modified Björk's cephalometric analysis in southern Chinese children were established. The use of specific standards for Chinese and separate for gender, for the modified Björk' cephalometric analysis seems to be justified.
\end{abstract}

Key Words: Cephalometrics, diagnosis, population norms, ethnic, gender.

\section{INTRODUCTION}

'Since its introduction in 1931 by Broadbent and Hofrath in the United States and Germany, respectively, radiographic cephalometry has become one of the most important tools of clinical and research orthodontics' [1]. Lateral cephalometry radiograph is used for the orthodontic diagnosis and treatment planning, evaluation of treatment progress, treatment changes, growth study and research. A list of the most wellknown and popular cephalometric analyses included no fewer than 23 analyses introduced between 1946 and 1985 were presented in a contemporary comprehensive textbook on cephalometry [2]. 'Björk analysis' [3] is one of the most commonly used cephalometric method with some modifications. The vast majority of the 23 analyses used reference values obtained from selected, often small, samples of Caucasians, and some of these methods [4,5] made no distinction for age and gender. One method [6] included reference values based a small sample, separate for gender, over a 15-year age range, whereas for a few methods [3,7] the references were based on larger samples separate for gender and age groups.

For the appropriate application of any cephalometric analysis, it must be used with norms derived from popula-

*Address correspondence to this author at the Orthodontics, Faculty of Dentistry, The University of Hong Kong, Prince Philip Dental Hospital, 34 Hospital Road, Hong Kong SAR, China. E-mail: fyoung@ @kucc.hku.hk tions similar to the orthodontic patients with regard to ethnic group, gender and age [1]. Since orthodontic patients nowadays range from juveniles to senior citizens and come from various ethnic groups, a wide range of representative norms would be ideal. Nevertheless, patients most commonly undergo orthodontic treatment at around 10-14 years of age, and priority should be given to obtaining solid norms for this age group. Previously cephalometric norms in southern Chinese have been published [8] for a method described by Solow and Tallgren [9], McNamara Analysis [10] and Pancherz' sagittal (SO) and vertical (VO) occlusal analyses [11]. However Cooke and Wei [8] only used 60 per cent of the available Chinese sample and the ethnic comparison was limited to males only [12]. In a recent addition to this series of cephalometric norms of southern Chinese the reference values interpolation of the increments obtained from another population study estimates of annual increments were made in order to get reference values, not only for 12-year old but for the age range of 10-14 years [10], when many children undergo orthodontic treatment. Therefore the aim of this study to establish cephalometric norms of modified Björk analysis for southern Chinese children.

\section{MATERIALS AND METHODS}

Two hundred male and 207 female 12-year-old southern Chinese school children were selected by a partially stratified random sampling method from ten schools in Hong Kong [8]. Two females with previous and current orthodon- 
tic treatment were excluded, and the final sample consisted of 200 males and 205 females (Table 1). In addition a sample was drawn from two expatriate schools which agreed to participate in the study, consisting of 47 male and 43 female 12year old Caucasian school children living in Hong Kong whose parents originated from the United Kingdom. This sample was used for ethnic comparison. Four male Caucasians were excluded from the initial sample due to previous or current orthodontic treatment, and the final sample consisted of 43 males and 43 females.

\section{RADIOGRAPHIC TECHNIQUE}

All the lateral cephalometric radiographs were taken in natural head posture as originally defined by Molhave [13] and later adopted and modified by others $[14,15]$. The x-ray machine was General Electric GE1000 (Milwaukee, WI) using for both Chinese and Caucasian samples. Magnification was 8.8 percent for the mid-sagittal structure, ear-rods were used, and the subjects looked into a mirror $200 \mathrm{~cm}$ ahead after first tilting the head forward and backward with decreasing amplitude until a comfortable position of natural balance was found [15]. The lips were in light contact. Intensifying screens were used to minimize the exposure level. Free comprehensive dental treatment including orthodontic treatment was offered to all subjects, and copies of the original radiographs were later used for diagnosis.

\section{CEPHALOMETRIC METHOD}

The landmarks and reference lines for modified Björk analysis [3] are summarized in Table 2 . Initially, the radiographs were traced manually and then rechecked by digitization and application of the program CASSOS (CASSOS 2001, Soft Enable Technology Limited, Hong Kong, PRC). There was no statistically-significant difference between the method error of the tracing by manual and digitizer. All radiographs were traced and digitized twice, talking the average of each of the investigated cephalometric variables in order to reduce the error in landmark identification [16]. Besides the actual population reference values for 12-year old children, additional 'reference values' for the ages 10, 11, 13 and 14 year-old children, were extrapolated from increments obtained from the analysis of template obtained from Scandinavian standards $[17,18]$.

\section{STATISTICAL ANALYSIS}

T-test for independent samples was used, and the levels of statistical significance were $P<.05, P<.01$ and $P<.001$. The gender differences and the ethnic differences were also presented in standard deviation-score [19]; i.e. for a certain variable A:

1) SD Score of gender difference of variable A:

$$
\begin{gathered}
\text { Mean of gender difference } \\
\text { (SD of A for males + SD of A for females }) / 2
\end{gathered}
$$

2) SD Score of ethnic difference of variable A:

Mean of ethnic difference A

(SD of A for Chinese males $+\mathrm{SD}$ of $\mathrm{A}$ for Caucasian males)/2

\section{METHOD ERROR}

Method errors were calculated by Dahlberg's formula [20], M.E $=\sqrt{\frac{\sum d^{2}}{2 n}}$. Where $\sum d^{2}$ is the sum of the squared differences between the two sets of two mean values, and $\mathrm{n}$ is the number of double measurements.

\section{RESULTS}

All radiographs were traced and digitized twice, taking the average of each of the investigated cephalometric variables in order to reduce the error in landmark identification [16]. The method errors for linear and angular measurement were not statistically significant, and did not exceed $0.5 \mathrm{~mm}$ and $0.7^{\circ}$ respectively for any variables. There was no statistically-significant difference between the age groups of the samples (Table 1). The cephalometric norms of modified

\begin{tabular}{|c|c|c|c|c|c|c|}
\hline & \multirow[b]{2}{*}{$\mathbf{n}$} & \multicolumn{3}{|c|}{ Age } & \multicolumn{2}{|c|}{ Range } \\
\hline & & Mean & SD & Median & Minimum & Maximum \\
\hline \multicolumn{7}{|l|}{ Chinese } \\
\hline Male & 200 & 12.4 & 0.60 & 12.5 & 11.0 & 13.0 \\
\hline Female & 205 & 12.5 & 0.38 & 12.6 & 11.9 & 13.0 \\
\hline Difference $^{\text {a) }}$ & & -0.1 & & -0.1 & -0.9 & 0.0 \\
\hline \multicolumn{7}{|l|}{ Caucasian } \\
\hline Male & 43 & 12.4 & 0.20 & 12.4 & 12.1 & 12.7 \\
\hline Female & 43 & 12.5 & 0.32 & 12.3 & 12.1 & 13.0 \\
\hline Difference $^{\text {a) }}$ & & -0.1 & & 0.1 & 0.0 & -0.3 \\
\hline
\end{tabular}

Table 1. Demographic Data on the Chinese and Caucasian Samples

a) Sex difference was not statistically significant. 
Table 2. Landmarks and Definitions

\begin{tabular}{|c|c|c|}
\hline $\begin{array}{c}\text { Abbreviation } \\
\text { S }\end{array}$ & $\begin{array}{c}\text { Landmark } \\
\text { Sella }\end{array}$ & The center of sella turcica \\
\hline $\mathrm{N}$ & Nasion & The most anterior limit of suture nasofrontalis \\
\hline $\mathrm{Ba}$ & Basion & The posterior interior point on the occipital bone at the anterior margin of the foramen magnum \\
\hline PNS & Posterior Nasal Spine & The apex of the posterior nasal spine \\
\hline A & Subspinale & The most posterior point on the concave anterior border of the maxillary alveolar process \\
\hline B & Supramentale & Innermost point on the anterior contour of the mandible \\
\hline $\mathrm{Pg}$ & Pogonion & The most anterior point on the mandibular symphysis \\
\hline $\begin{array}{c}\text { Angles } \\
\text { NSBa }\end{array}$ & & The angle formed by the anterior (NS) and posterior skull base (SBa) \\
\hline SNA & & The angle formed by the SN and NA lines \\
\hline SNB & & The angle formed by the SN and NB lines \\
\hline ANB & & The angle formed by the AN and NB lines \\
\hline SNPg & & The angle formed by the SN and NPg lines \\
\hline $\mathrm{SN} / \mathrm{MnPl}$ & & The angle formed by the SN line and the mandibular plane \\
\hline $\mathrm{SN} / \mathrm{MxPl}$ & & The angle formed by the SN line and the maxillary plane \\
\hline $\begin{array}{c}\text { Distances } \\
\text { Lower I to A-Pg }\end{array}$ & & The distance From the tip of the lower incisor to the A-Pg line \\
\hline $\mathrm{A}, \mathrm{B}$ on $\mathrm{OP}$ & & The distance between the projections from A and B points to the functional occlusal plane \\
\hline UFH & & Upper facial height: the distance from Nasion to $\mathrm{MxPl}$ \\
\hline LFH & & Lower facial height: the distance from MxPl to Menton \\
\hline Upper Lip to E & & The distance from the upper lip to the esthetic line \\
\hline Lower lip to $\mathrm{E}$ & & The distance from the lower lip to the esthetic line \\
\hline
\end{tabular}

Björk analysis [3] for 12-year old southern Chinese and 12year old British Caucasian are summarized in Table $\mathbf{3}$ and Table 4, respectively. The inter-ethnic differences for males and females are summarized in Table 5. There was a large individual variation for all variables for both ethnic groups and both genders.

\section{GENDER DIFFERENCES (TABLES 3 AND 4)}

There was no statistically-significant gender difference among the Chinese subjects for the variables of skull base angle, SNA, SN to maxillary plane angle, upper incisor to maxillary angle, lower incisor to mandibular plane angle, interincisal angle and lower incisor to A-Pg. Eight variables among the Chinese subjects were significantly larger in males: ANB $\left(0.9^{\circ} ; 0.4\right.$ SD score $\left.\mathrm{P}<0.001\right)$, SN to mandibular plane angle $\left(1.7^{\circ} ; 0.3 \mathrm{SD}\right.$ score, $\left.\mathrm{P}<0.01\right)$, maxillary plane to mandibular plane angle $\left(1.6^{\circ} ; 0.3 \mathrm{SD}\right.$ score, $\left.\mathrm{P}<0.01\right)$, Wits appraisal $(0.7 \mathrm{~mm} ; 0.3 \mathrm{SD}$ score, $\mathrm{P}<0.01)$, upper facial height $(1.3 \mathrm{~mm}$; 0.4 SD score, $\mathrm{P}<0.01)$, lower facial height $(1.2 \mathrm{~mm}$; 0.3 SD score, $\mathrm{P}<0.01)$, upper lip to esthetic line $(1.7 \mathrm{~mm} ; 0.8$ $\mathrm{SD}$ score, $\mathrm{P}<0.001)$, and lower lip to esthetic line $(1.7 \mathrm{~mm}$; 
Table 3. Cephalometric Norms of Modified Björk's Analysis for 12-Year Old Chinese Children

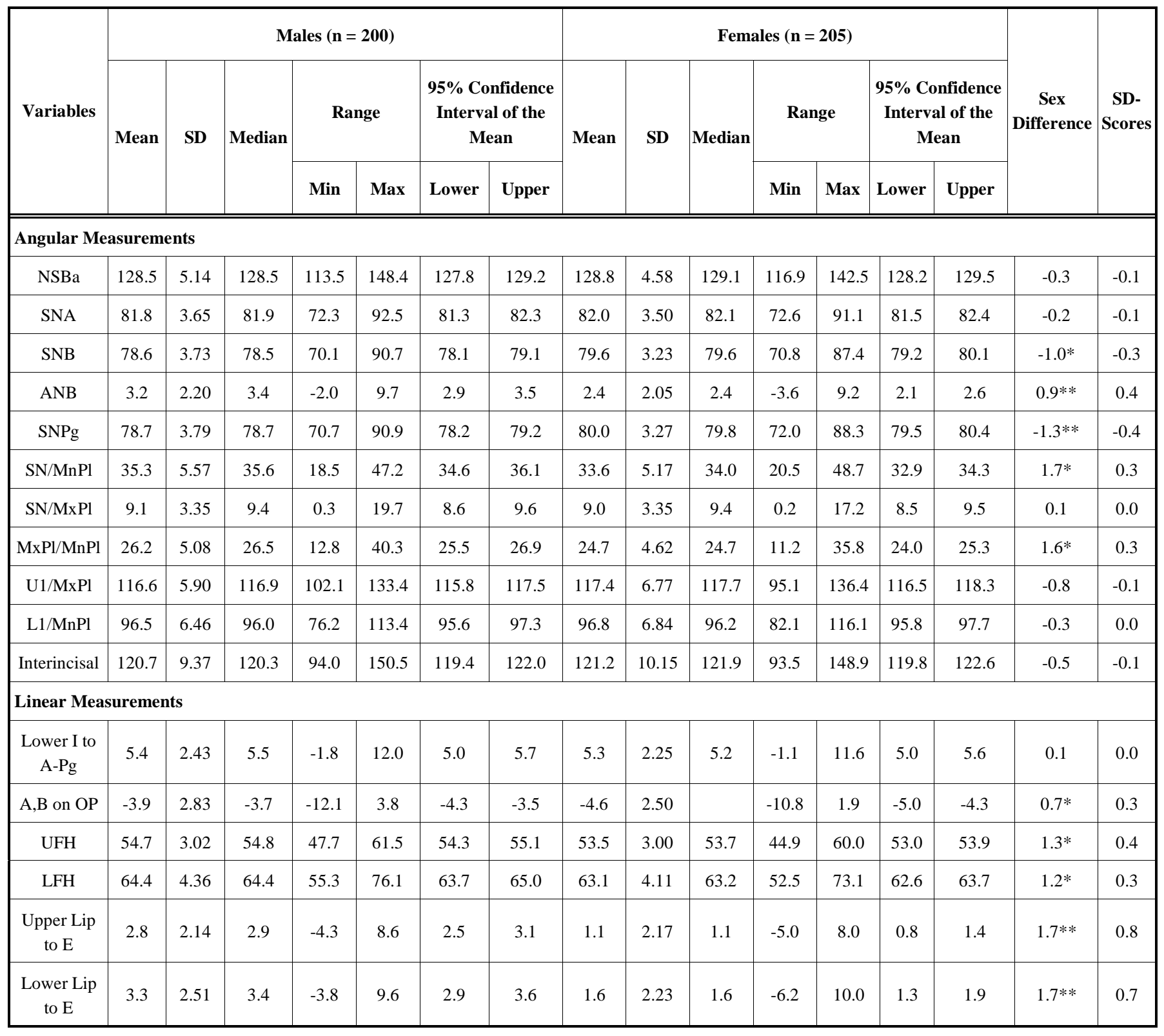

$*: \mathrm{p}<0.01 ; * *: \mathrm{p}<0.001$.

0.7 SD score, $\mathrm{P}<0.001)$. Two variables were significantly larger in females: SNB $\left(-1.0^{\circ}\right.$; $-0.3 \mathrm{SD}$ score, $\left.\mathrm{P}<0.01\right)$, SN to pogonion angle $\left(-1.3^{\circ} ;-0.4 \mathrm{SD}\right.$ score, $\left.\mathrm{P}<0.001\right)$.

Among the Caucasian subjects, statistically-significant gender differences were noted for three parameters: lower face height $(2.2 \mathrm{~mm}$; 0.5 SD score, $\mathrm{P}<0.01)$, upper lip to esthetic line $(1.2 \mathrm{~mm}$; 0.6 SD score, $\mathrm{P}<0.01)$, and lower lip to esthetic line $(1.4 \mathrm{~mm} ; 0.6 \mathrm{SD}$ score, $\mathrm{P}<0.01)$. They were larger in males than in females (Table 4).

\section{ETHNIC DIFFERENCES (TABLE 5)}

Among the male subjects statistically-significant differences were noted for six variables related to the angular measurements, and five variables related to the linear variables. Nine of the variables were larger in the Chinese sub- jects, five angular measurements, SNA $\left(1.5^{\circ} ; 0.3\right.$ SD score, $\mathrm{P}<0.01)$, SNB $\left(0.8^{\circ} ; 0.2\right.$ SD score, $\left.\mathrm{P}<0.05\right)$, SN to mandibular plane angle $\left(3.7^{\circ} ; 0.8 \mathrm{SD}\right.$ score, $\left.\mathrm{P}<0.001\right)$, SN to maxillary plane angle $\left(2.7^{\circ} ; 0.6 \mathrm{SD}\right.$ score, $\left.\mathrm{P}<0.001\right)$, upper incisor to maxillary plane angle $\left(4.8^{\circ} ; 1.0 \mathrm{SD}\right.$ score, $\left.\mathrm{P}<0.001\right)$, and four linear measurements, lower incisor to A-Pg line (3.2 $\mathrm{mm}$; 0.7 SD score, $\mathrm{P}<0.001)$, upper facial height $(3.0 \mathrm{~mm}$; $0.6 \mathrm{SD}$ score, $\mathrm{P}<0.001)$, upper lip to esthetic line $(4.1 \mathrm{~mm}$; 0.8 SD score, $\mathrm{P}<0.001)$ and lower lip to esthetic line $(4.1$ $\mathrm{mm}$; 0.9 SD score, $\mathrm{P}<0.001)$, whereas two variables were larger in the Caucasian subjects, i.e. interincisal angle $\left(-7.7^{\circ}\right.$; $-1.6 \mathrm{SD}$ score, $\mathrm{P}<0.001)$, and Wits appraisal $(-1.0 \mathrm{~mm} ;-0.2$ $\mathrm{SD}$ score, $\mathrm{P}<0.05)$.

In females, nine out of eleven variables related to the angular measurements and all six variables related to linear measurements, differed significantly. Eleven variables were 
Table 4. Cephalometric Norms of Modified Björk's Analysis for 12-Year Old Caucasian Children

\begin{tabular}{|c|c|c|c|c|c|c|c|c|c|c|c|c|c|c|c|c|}
\hline \multirow[t]{2}{*}{ Variables } & \multirow[t]{2}{*}{ Mean } & \multirow[t]{2}{*}{ SD } & \multirow[t]{2}{*}{ Median } & \multicolumn{2}{|c|}{ Range } & \multicolumn{2}{|c|}{$\begin{array}{l}\text { 95\% Confidence } \\
\text { Interval of the } \\
\text { Mean }\end{array}$} & \multirow[t]{2}{*}{ Mean } & \multirow[t]{2}{*}{ SD } & \multirow[t]{2}{*}{ Median } & \multicolumn{2}{|c|}{ Range } & \multicolumn{2}{|c|}{$\begin{array}{c}\text { 95\% Confidence } \\
\text { Interval of the } \\
\text { Mean }\end{array}$} & \multirow[t]{2}{*}{$\begin{array}{c}\text { Sex } \\
\text { Difference }\end{array}$} & \multirow[t]{2}{*}{$\begin{array}{l}\text { SD- } \\
\text { Score }\end{array}$} \\
\hline & & & & Min & Max & Lower & Upper & & & & Min & $\operatorname{Max}$ & Lower & Upper & & \\
\hline NSBa & 129.2 & 4.49 & 129.3 & 118.6 & 140.0 & 128.6 & 129.8 & 131.0 & 4.55 & 130.3 & 121.8 & 142.9 & 130.3 & 131.6 & -1.8 & -0.4 \\
\hline SNA & 80.3 & 2.72 & 80.7 & 73.5 & 87.0 & 79.9 & 80.6 & 80.9 & 3.49 & 80.9 & 72.1 & 89.8 & 80.4 & 81.3 & -0.6 & -0.2 \\
\hline SNB & 77.7 & 2.56 & 77.4 & 72.8 & 83.6 & 77.4 & 78.1 & 77.6 & 3.16 & 78.1 & 69.0 & 84.3 & 77.2 & 78.0 & 0.1 & 0.0 \\
\hline $\mathrm{SN} / \mathrm{MxPl}$ & 6.4 & 3.08 & 7.0 & 0.7 & 13.9 & 6.0 & 6.8 & 7.6 & 2.71 & 7.6 & 1.8 & 14.0 & 7.3 & 8.0 & -1.2 & -0.4 \\
\hline $\mathrm{MxPl} / \mathrm{MnPl}$ & 25.3 & 4.36 & 25.1 & 13.0 & 35.7 & 24.7 & 25.9 & 23.6 & 5.64 & 23.8 & 7.6 & 36.0 & 22.9 & 24.4 & 1.6 & 0.3 \\
\hline $\mathrm{U} 1 / \mathrm{MxPl}$ & 111.8 & 6.02 & 111.5 & 97.1 & 125.3 & 111.0 & 112.7 & 111.5 & 5.84 & 111.7 & 96.2 & 130.2 & 110.7 & 112.3 & 0.3 & 0.1 \\
\hline $\mathrm{L} 1 / \mathrm{MnPl}$ & 94.5 & 5.73 & 94.3 & 84.4 & 107.5 & 93.7 & 95.3 & 95.8 & 7.05 & 94.6 & 79.7 & 109.9 & 94.8 & 96.7 & -1.3 & -0.2 \\
\hline Interincisal & 128.4 & 8.76 & 127.9 & 113.0 & 144.2 & 127.2 & 129.6 & 129.1 & 10.03 & 130.9 & 105.3 & 154.1 & 127.7 & 130.5 & -0.7 & -0.1 \\
\hline \multicolumn{17}{|c|}{ Linear Measurements } \\
\hline $\begin{array}{c}\text { Lower I to } \\
\text { A-Pg }\end{array}$ & 2.1 & 2.28 & 2.1 & -1.5 & 8.4 & 1.8 & 2.5 & 1.5 & 2.36 & 1.5 & -4.4 & 6.5 & 1.2 & 1.9 & 0.6 & 0.3 \\
\hline $\begin{array}{l}\text { Lower Lip } \\
\quad \text { to } \mathrm{E}\end{array}$ & -0.8 & 2.21 & -0.5 & -5.3 & 3.0 & -1.1 & -0.5 & -2.2 & 2.77 & -2.5 & -7.2 & 4.9 & -2.6 & -1.9 & $1.4^{*}$ & 0.6 \\
\hline
\end{tabular}

$*: \mathrm{p}<0.01$.

statistically-significantly larger in Chinese females, SNA $\left(1.1^{\circ} ; 0.2 \mathrm{SD}\right.$ score, $\left.\mathrm{P}<0.05\right)$, SNB $\left(2.0^{\circ} ; 0.4 \mathrm{SD}\right.$ score, $\mathrm{P}<0.001)$, SN to pogonion angle $\left(1.3^{\circ} ; 0.3\right.$ SD score, $\mathrm{P}<0.01)$, SN to mandibular plane angle $\left(2.4^{\circ} ; 0.5 \mathrm{SD}\right.$ score, $\mathrm{P}<0.01), \mathrm{SN}$ to maxillary plane angle $\left(1.4^{\circ} ; 0.3 \mathrm{SD}\right.$ score, $\mathrm{P}<0.05)$, upper incisor to maxillary plane angle $\left(6.0^{\circ} ; 1.3 \mathrm{SD}\right.$ score, $\mathrm{P}<0.001)$, lower incisor to A-Pg line $(3.7 \mathrm{~mm}$; $0.8 \mathrm{SD}$ score, $\mathrm{P}<0.001)$, upper facial height $(1.7 \mathrm{~mm}$; $0.4 \mathrm{SD}$ score, $\mathrm{P}<0.01)$, lower facial height $(2.3 \mathrm{~mm} ; 0.5 \mathrm{SD}$ score, $\mathrm{P}<0.01)$, upper lip to esthetic line $(3.5 \mathrm{~mm}$; $0.8 \mathrm{SD}$ score, $\mathrm{P}<0.001)$, and lower lip to esthetic line $(3.9 \mathrm{~mm} ; 0.8 \mathrm{SD}$ score, $\mathrm{P}<0.001)$. Four variables were larger in Caucasian females: skull base angle $\left(-2.1^{\circ} ;-0.5\right.$ SD score, $\left.\mathrm{P}<0.01\right)$, ANB $\left(-0.9^{\circ}\right.$; 0.2 SD score, $\mathrm{P}<0.01)$, interincisal angle $\left(-7.9^{\circ} ;-1.7 \mathrm{SD}\right.$ score, $\mathrm{P}<0.001)$ and Wits appraisal $(-2.5 \mathrm{~mm} ;-0.5 \mathrm{SD}$ score, $\mathrm{P}<0.001)$.

\section{REFERENCE VALUES FOR CERTAIN AGE GROUPS}

The mean values for the cephalometric variables for 10 to 14 years, separate for sex and ethnic groups, respectively, are given in Table 6.

\section{DISCUSSION}

This study established norms for modified Björk analysis [3] in southern Chinese, separate for gender. The study was based on a large sample of 12 year old children which was representative for its original population [8]. In the study the cephalograms were measured twice and the averaged figures were used. These repeated measurements reduced the error of landmark identification [16], and duplicate measurements were sufficient for a comparison of the two groups. Consequently the means and standard deviations of the seventeen 
Table 5. Cephalometric Norms of Modified Björk's Analysis for Inter-Ethnic Differences (Chinese vs Caucasians)

\begin{tabular}{|c|c|c|c|c|}
\hline Variables & Male & SD-Score & Female & SD-Score \\
\hline \multicolumn{5}{|c|}{ Angular Measurements } \\
\hline SNA & $1.5 * *$ & 0.3 & $1.1 *$ & 0.2 \\
\hline SNPg & -0.2 & 0.1 & $1.3 * *$ & 0.3 \\
\hline $\mathrm{SN} / \mathrm{MnPl}$ & $3.7 * * *$ & 0.8 & $2.4 * *$ & 0.5 \\
\hline $\mathrm{SN} / \mathrm{MxPl}$ & $2.7 * * *$ & 0.6 & $1.4 *$ & 0.3 \\
\hline $\mathrm{L} 1 / \mathrm{MnPl}$ & 1.9 & 0.3 & 1.0 & 0.2 \\
\hline Interincisal & $-7.7 * * *$ & -1.6 & $-7.9 * * *$ & -1.7 \\
\hline \multicolumn{5}{|c|}{ Linear Measurements } \\
\hline Lower I to A-Pg & $3.2 * * *$ & 0.7 & $3.7 * * *$ & 0.8 \\
\hline $\mathrm{A}, \mathrm{B}$ on $\mathrm{OP}$ & $-1.0 *$ & -0.2 & $-2.5 * * *$ & -0.5 \\
\hline UFH & $3.0 * * *$ & 0.6 & $1.7 * *$ & 0.4 \\
\hline LFH & 1.4 & 0.3 & $2.3 * *$ & 0.5 \\
\hline
\end{tabular}

$*: \mathrm{p}<0.05 ; * *: \mathrm{p}<0.01 ; * * *: \mathrm{p}<0.001$.

cephalometric variables investigated in this study should be considered as representative for 12-year-old southern Chinese. In a previous study [8] which was based a part (60 per cent) of the current sample of southern Chinese children, the cephalograms were analysed once only, seven out our 17 cephalometric variables were not included, and the ethnic comparison was limited to males only [12]. Subsequently, the reference data obtained in this study was based on larger, probably more representative sample of southern Chinese children, are of higher quality since the data was based on the average of two readings [16]. Moreover the analysis included a matched female Caucasian cohort, so the ethnic comparison could include both sexes, and the sex difference between Caucasian males and females could be investigated.

Besides a conventional statistical t-test of the differences between variables for the two genders and the two ethnic groups, SD scores were also used. The statistically-significant gender differences among the Chinese subjects and the ethnic differences between Chinese and Caucasians (Tables 3, 4 and 5) were also expressed in standard deviation scores [19]. In other words, the differences were expressed not only in degrees and millimeters, but also in relation to their variation around the mean of the actual parameter. To use SD scores to describe the extent to which a certain patient devi- ated for specific cephalometric variables can also be used in clinical situations $[10,11,19,21]$.

\section{ETHNIC DIFFERENCES}

In the present study a direct ethnic comparison of both sexes was made between 12-year old Chinese and 12-year old Caucasian children (Table 5), whereas in the previous study on material obtained from the same cohorts, the ethnic gender comparison was limited to males only [12].

This study showed marked ethnic differences for eleven out the seventeen variables of male and fifteen out of seventeen variables of female between the Chinese and Caucasian samples (Table 5). The statistically-significant ethnic differences expressed in SD Scores [19] ranged from -1.6 to 1.0 in males and -1.7 to 1.3 in females for modified Björk analysis in this study. This degree of difference would appear to justify separated cephalometric standards for Chinese and Caucasian children. Such ethnic differences were to be expected, since a similar ethnic pattern was noticed from comparison of those samples when adopting the cephalometric method devised by Solow and Tallgren [9] on this sample [12]. The pattern of ethnic differences in males of this study and the previous study, was identical except for the inclination of the lower incisor to the mandibular plane, with not statistically 
Table 6. Reference Values for Modified Björk's Analysis for 10-14 Year Old Chinese and Caucasian Females and Males

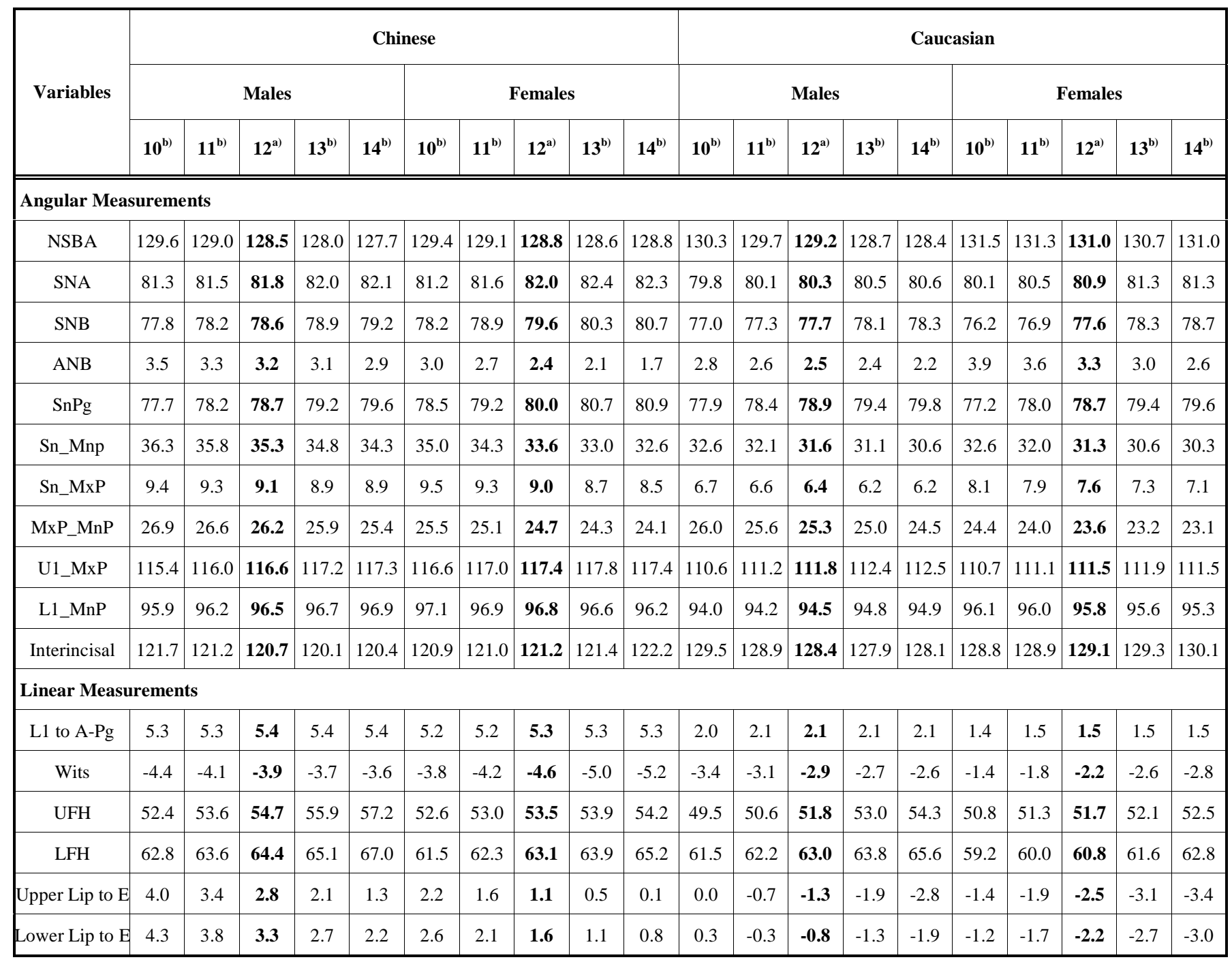

a) Reference values of 12-year old children of this study.

b) Reference values based on increments obtained from another (Thilander et al., 2005).

significant ethnic difference in this study, neither for females (Table 5). Ethnic differences in conventional cephalometric methods have also been reported for Chinese versus Indians and Malays respectively [22], and Chinese versus Caucasian samples with malocclusions [23,24].

\section{GENDER DIFFERENCES}

In this study there was a statistically-significant difference between male and female Chinese subjects for eight out of the seventeen variables (Table 3). Expressed in SD Scores [19] these gender differences were -0.4 to 0.8 . The mandible was significantly more retrognathic, the $\mathrm{SN}$ to mandibular plane angle and maxillary to mandibular plane angle were steeper, and lower face height was larger in males. The Chinese male had a longer face than female because the upper and lower facial height were statistically-significant longer. Upper and lower lip to the esthetic line were statistically significant larger in male that means the Chinese male had a more fullness of lip. Previous cephalometric studies have indicated that there were some gender differences in the con- ventional cephalometric parameters among Chinese populations [25-27].

In the Caucasian sample used in this study the gender differences of the cephalometric parameters were not marked with the exception of lower face height, upper and lower lip to the esthetic line (Table 4). This is consistent with a report that both angular and linear measurements in both genders in Caucasians were in general agreement [28]. Normative standards of modified Björk analysis for 10-,11-,13- and 14year-old were estimated from values obtained from measurement obtained and interpolated from template of Swedish population study $[17,18]$ and subtracted and added, respectively, to the standards of the 12 year-old of the present study, in an attempt to provide cephalometric standards for wider age range, separate for gender and ethnic group (Table 6).

In this study there was statistically significant sex difference in the Chinese cohort for half of the investigated cephalometric hard tissue variables $(8 / 15)$, whereas in the previous study [9] only 20 per cent out the variables (5/26) were 
different between the sexes. Of the eight hard-tissue cephalometric variables which were included in both studies, there was statistically significant sex difference for 3 only in this study, and two only in the other study, none in common. The two statistically significant sex difference in the previous study were related to the inclination of the lower incisor, which also had statistically significant ethic difference between males in the previous study [12], whereas no ethnic difference was found in this study for either sex (Table 5).

\section{CONCLUSION}

Cephalometric norms for the modified Björk's cephalometric analysis in southern Chinese children were established. It seems to be justifiable to use specific Chinese norms and separate for gender since this study has revealed that there were statistically significant differences in most cephalometric variables between Chinese males and females, and between Chinese and Caucasians children.

\section{ACKNOWLEDGEMENTS}

The lateral cephalograms were part of the oral health survey of 12-year old children collected by Dr. M.S. Cooke in 1984-85. That study was supported by the research grant no. 335.251.0001 of the Faculty of Dentistry, University of Hong Kong.

\section{REFERENCES}

[1] Athanasiou A. Orthodontic Cephalometry. London: Mosby-Wolfe 1997; p. 296.

[2] Bosch C, Athanasiou A. Landmarks, variables and norms of various numerical cephalometric analyses - cephalometric morphologic and growth data references. In: Athanasiou A, Ed. Orthodontic Cephalometry. London: Mosby-Wolfe 1997; 241-92.

[3] Björk A. The face in profile - an anthropological X-ray investigation on Swedish children and conscripts. Svensk Tandläkare - Tidskrift 1947; 40(Suppl 5B).

[4] Jarabak JR, Fizzell JA. Technique and treatment with lightwire edgewise appliance. CV Mosby: St Louis; 1972.

[5] Holdaway RA. A soft-tissue cephalometric analysis and its use in orthodontic treatment planning. Part I. Am J Orthod 1983; 84: 128.

[6] Burstone CJ, James RB, Legan H, Murphy GA, Norton LA. Cephalometrics for orthognathic surgery. J Org Surg 1979; 36: 269-77.

[7] Harvold EP. The activator in orthodontics. CV Mosby: St Louis 1974; pp. 37-56.
[8] Cooke MS, Wei SH. Cephalometric standards for the southern Chinese. Eur J Orthod 1988; 10: 264-72.

[9] Solow B, Tallgren A. Head posture and craniofacial morphology. Am J Phys Anthrop 1976; 44: 417-36

[10] Wu J, Hagg U, Rabie ABM. Chinese norms of McNamara's cephalometric analysis. Angle Orthod 2007; 77: 12-20.

[11] Wu J, Hagg U, Pancherz H, Wong R, Colman M. Chinese and caucasian norms of Pancherz' cephalometric sagittal (SO) and vertical (VO) occlusal analyses. Am J Orthod Dentofac Orthop 2009; in press.

[12] Cooke MS, Wei SH. A comparative study of southern Chinese and British Caucasian cephalometric standards. Angle Orthod 1989; 59: 131-8.

[13] Molhave A. Sitting \& standing posture in man. Ugeskr Laeger 1958; 120: 1516-8.

[14] Solow B, Tallgren A. Natural head position in standing subjects. Acta Odontol Scand 1971; 29: 591-607.

[15] Siersbaek-Nielsen S, Solow B. Intra- and interexaminer variability in head posture recorded by dental auxiliaries. Am J Orthod 1982; 82: 50-57.

[16] Miethke RR. Zur Lokalisationsgenauigkeit kephalometrischer Referenzpunkte. Prakt Kieferorthop 1989; 3: 107-122.

[17] Persson M, Thilander B. Templates for cephalometric analysis. Invest-Odont AB 1987; p. 11.

[18] Thilander B, Persson M, Adolfsson U. Roentgen-cephalometric standards for a Swedish population. A longitudinal study between the ages of 5 and 31 years. Eur J Orthod 2005; 27: 370-89.

[19] Karlberg P, Taranger J. The Somatic Development of Children in a Swedish Urban Community. Acta Paediatr Scand Suppl 1976; 258 : 7-76.

[20] Dahlberg G. Statistical methods for medical and biological students. Allen \& Unwin, London 1940.

[21] Kjellberg H, Albrektson WK. A longitudinal study of craniofacial growth in ideopathic short stature and growth hormone-deficient boys treated with growth hormone. Eur J Orthod 2007; 29: 243-50.

[22] Lew KK. Cephalometric ideals in Chinese, Malay and Indian ethnic groups. Asian J Aesthet Dent 1994; 2: 35-8.

[23] Zeng XL, Forsberg CM, Linder-Aronson S. Craniofacial morphology in Chinese and Swedish children with Angle Class I and Class II occlusal relations. Aust Orthod J 1998; 15: 168-76.

[24] Lau JW, Hägg U. Cephalometric morphology of Chinese with Class II division 1 malocclusion. Br Dent J 1999; 186: 188-90.

[25] Lou ZH. Roentgenographic cephalometric study of 128 children with normal occlusion in Shanghai (in Chinese). Zhonghua Kou Qiang Ke Za Zhi 1981; 16: 100-3.

[26] Moate SJ, Darendeliler MA. Cephalometric norms for the Chinese: a compilation of existing data. Aust Orthod J 2002; 18: 19-26.

[27] Yeong P, Huggare J. Morphology of Singapore Chinese. Eur J Orthod 2004; 26: 605-12.

[28] Thilander B, Persson M, Skagius S. Roentgencephalometric standards for the facial skeleton and soft tissue profile of Swedish children and young adults. II. Comparisons with earlier Scandinavian normative data. Swed Dent J Suppl 1982; 15: 219-28. 